\title{
A Critical Study of how the Taliban Capitalize on Electronic Media Sensationalism in Pakistan
}

\section{Syed Adnan Haider*}

Associated Press of Pakistan, General Reporting 18-Mauve Area, Zero Point Islamabad, Pakistan

\begin{abstract}
The terrorist attacks of 9/11 in the USA jolted the world. Groups like Al-Qaeda and the Tehrik-e-Taliban Pakistan (TTP) emerged as strong organizations with supporters from various countries of the world. America in an attempt to crackdown on Al-Qaeda leaders began a war in Afghanistan and later also carried out attacks in various other Middle Eastern states. Whether or not the US achieved its war goals, the Taliban on the other hand did succeed in winning the support of a big number of people, especially by capitalizing on media's sensational reporting. The Taliban used media as one of the crucial tools and through it propagated their agenda. The strategy they adopted was to carry out terrorist attack and then accept the responsibility on media by releasing stance of their leaders to extend the scope of their terror by reaching out maximum people. Pakistan assumed the role of a front-line state in the war on terrorism but witnessed huge losses in terms of human causalities, infrastructure damage and economic recession from 2007 to 2014 . However, there was one industry that saw boom in the country, the media. The war on terrorism and media's mushroom growth took place side by side and apparently it seemed that media deliberately served the TTP by glorifying their activities, screening interviews of their leaders and creating sensationalism on terrorists' incidents. By giving undue coverage to the TTP in the name of "freedom of expression", the electronic media like in a thug of war for rating violated journalism ethics. This study posits that electronic media promoted pack journalism in Pakistan and every channel presented incidents of terrorism as breaking news for financial profit. They made it difficult for the government and security forces of a nuclear state to curb the menace of terrorism in the presence of an outspoken media industry.
\end{abstract}

\section{Keywords: TTP; Media; Sensationalism; Social responsibility}

\section{Introduction}

Media's role cannot be overlooked in a democratic society. It shapes public opinion, affects government policies and builds the image of society. Being the fourth pillar of a democratic state, media's responsibilities multiply. It has to act responsibly and sensibly with a view to keep the people informed, harmonized and united on sensitive issues, because sensational media creates disgust, fear and depression among the people. The tendency of broadcasting sensational news by cable / satellite channels without considering the consequences has been increasing steadily across the world [1]. Sensationalism in media is neither new terminology nor a new trend. It existed at the time when people used to tell stories to each other. The roots of sensationalism in history of press originated in the $16^{\text {th }}$ of century, the beginning of printing press [2-4]. Sensationalism in media is simply defined as projecting or reporting an event or news story by media in an "over-hyped" manner to attract maximum viewers, listeners or readers [5]. The higher viewership of a media channel or a newspaper eventually increases advertisements that ultimately multiply profit of the organization. Media groups prefer sensationalism more than objective reporting or journalism just for financial gains and to sustain viewership. According to George Taber, a former business editor of Time magazine and cofounder and editor of NJBIZ, "Sensation sells, more and more people get interested in the latest crime news than in the solution of the vogue energy crisis in the country or any other developmental aspect" [6]. Media industry across the globe and especially in developing countries including Pakistan has been using extremely hostile and loud-mouthed issues to sell [6]. Least attention is paid to the sensitivity of the issue and its effects on masses. The practice is still being followed across the world today.

The views of the scholars and writers vary regarding the right and wrong media sensationalism. The scholars believe that sensationalism on social issues like increasing polio cases in Pakistan, illiteracy, health etc. is important for public awareness [7] however sensational reporting on sensitive issues like terrorism, sectarianism, murder, crime, corruption and violence causes depression, fear and chaos in a society [1].

Turkish Prime Minister Recep Tayyip Erdogan in a statement in June 2010 blamed media of "serving the aims of the terror organizations" on coverage of terrorists' attack and discussing every opinion no matter whether it was of a terrorist or state dignity [8]. Pakistan, where media now enjoys an unprecedented liberty, is facing a challenging situation because here all a journalist needs to have is contact with leaders or spokesman of terrorist organizations to get their direct interviews and reaction over an incident to excel as a journalist. Leaders of terrorist organizations like Al-Qaeda and the Tehrik-e-Taliban Pakistan (TTP) have been gladly and readily releasing interviews using media as a mode of communication (Figure 1).

The TTP considered media a safe and powerful source of interaction to spread more terror in society without being detected by security forces. The electronic media channels in a bid to attract maximum viewers always took liberty and happily broadcast videos as released by

*Corresponding author: Syed Adnan Haider, Associated Press of Pakistan Islamabad, Federal Capital Pakistan, Tel:0923215236156; E-mail:haiderjournalist@ gmail.com

Received September 29, 2015; Accepted March 15, 2016; Published March 22, 2016

Citation: Haider SA (2016) A Critical Study of how the Taliban Capitalize on Electronic Media Sensationalism in Pakistan. J Mass Communicat Journalism 6 : 292. doi:10.4172/2165-7912.1000292

Copyright: (c) 2016 Haider SA. This is an open-access article distributed under the terms of the Creative Commons Attribution License, which permits unrestricted use, distribution, and reproduction in any medium, provided the original author and source are credited. 
the TTP in a sensational way and presented it as breaking news in every news bulletin, paying least attention to the content and sensitivity of the news (Figure 2).

With the rampant growth of media in Pakistan particularly the electronic media, the reliance of people on cable news channels has also incredibly increased. The nation, which is fed up with controlled transmission of state-run TV channel (PTV), all of a sudden gets inclined towards private TV channels to have 24/7 news. People even from developed countries also prefer to watch cable news channels instead of official ones to get comparatively uncensored news update. In America more than 50 per cent of total population gets news from cable news channels [9]. The developing nations, at internal war like Pakistan often thrive on conspiracies' theories and entirely depend on media to know what is happening around. But what they get is media sensationalism which creates more and more panic in society affecting the thinking and behavior of the masses [6].

\section{Growth of Electronic media in Pakistan}

Electronic media news channels made rapid growth in Pakistan after 2000 and quickly penetrated in the society where Pakistan Television (PTV) and Pakistan Radio Broadcast (PBC) were the only source of entertainment and news till the year 1999. Despite guaranteed freedom of expression in the constitution of Pakistan the media never enjoyed freedom until 2001; the former dictators and even democratic

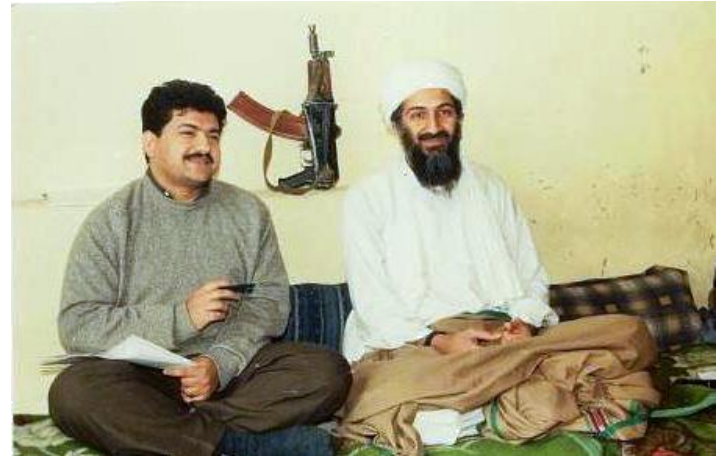

Figure 1: The Pakistani journalist Mr. Hamid Mir interviewing Osama bin Laden for Daily Dawn in 2001.

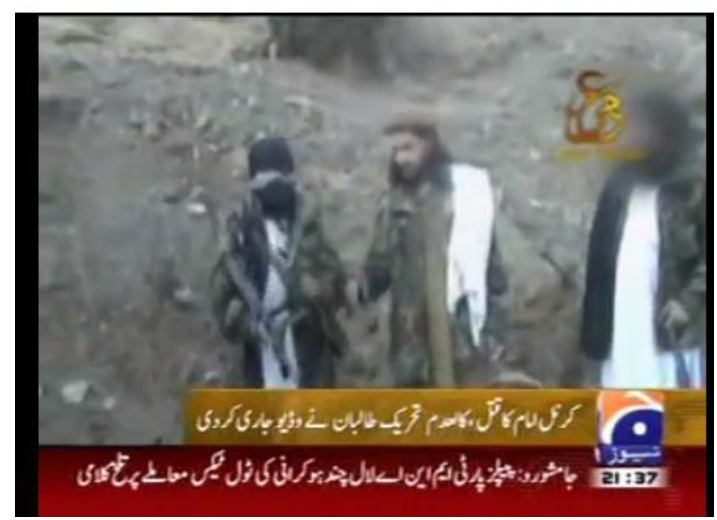

Figure 2: TTP former leader Hakimullah Mahsud is shown in a video in which Pakistan intelligence agency's (ISI) retire Col Imam was killed in front of TTP leader in January 2011. governments always kept the media freedom contained in the name of various ordinances. The most draconian act in the history of Pakistan was promulgated in 1980 by President of Pakistan General Zia-ul-Haq and was known as Press and Publication Ordinance (PPO). Under the PPO the media was not allowed to openly criticize the government's policies and even the government reserved the rights to seize a media group in reaction of any news. General Zia ul Haq's death led to restoration of democracy in Pakistan and enabled the lawmakers to ease the restrictions on the media under "Revised Press and Publication Ordinance" [10].

President General Pervaiz Musharraf, a military ruler, unlike General Zia ul Haq, allowed liberty to the media under the social responsibility theory. He established Pakistan Electronic Media Regulatory Authority (PEMRA) to issue licenses to electronic media channels. The owners of print media groups including Jang Groups, Express, Dawn and some private investors associated with the industry grabbed the opportunity and opened up electronic media channels as they found it a most lucrative business.

It is believed that the military ruler's policy of liberalization of media was an attempt to counter Indian media’s propaganda against Pakistan. Being a rival the Indian media always used very hostile mouth against Pakistan and left no stone unturned to defame the country across the globe. Pakistan faced the rage of Indian media on the issues of Kargil War in 1999 and hijacking of Indian Airlines Flight 814 on December $24^{\text {th }} 1999$ by militants [11]. The assessment of Pakistani military of liberalizing media to some extend helped Pakistan in countering Indian media's propaganda but by and large it was not a good idea as the media was supposed to act responsibly while keeping in view its social responsibilities. This very thing resulted in sensationalism and media's outspoken criticism on the government. In an environment of competition, the channels willfully violated PEMRA rules and regulation by broadcasting certain contents with a view to strengthen viewership. The PEMRA issued notices to many electronic media channels on violation of contents and even in some cases suspended licenses but the media group challenged the act of PEMRA in court. The loopholes in PEMRA act thus provided a sneaky way to media groups to continue their practices in violation of journalistic norms and for personal financial benefits [12].

The 9/11 terrorist attacks, followed by US invasion in Afghanistan in search of Al-Qaeda leaders, provided an opportunity to media groups in Pakistan to harness the situation and increase their viewership by giving full coverage to terrorist leaders and attacks. During the last 10 years the viewership of private TV channels reached between 115 to 135 million [13]. Currently there are as many as 59 operational TV channels in Pakistan while PEMRA has issued a total 71 licenses to private satellite TV channels during the last five years [14]. Since 2009 till March 2013, about 72 cases against different media groups were filed in Supreme Court, Sindh High Court, Muzaffarabad High Court, Lahore High Court and Islamabad High Court but all remained un-decreed as there was no legislation to bar the media from broadcasting contents against journalistic norms national security.

Terrorist groups like the Tehrik-e-Taliban Pakistan (TTP) and Al-Qaeda in Pakistan lately realised that violence needed to be made public to extend its scope. After the military operation against Islamic fundamentalists of Lal Mosque in July 2007 in Islamabad, the TTP learnt to exploit the media's own procedure and maximize their penetration among masses. They had sensed that a single bomb explosion might not instill as much fear and panic in the society as its propagation through media could do. Images, especially video images, of bombed 
buildings, bloody corpses and frightened hostages and then repeated dissemination and discussions on the topic by electronic media left long lasting psychological effects on many minds (Figure 3).

It was media that made mother of Malala Yousafzai, like thousands of other Swati women, a big fan of Taliban leader Maulana Fazlullah. He emerged as a spiritual leader, a deity for whom women of the area were ready to sacrifice their valuables [16].

Claiming responsibility for a terrorist attack on the media was one of the most effective ways to get free global publicity and the same was done by the TTP in Pakistan. The TTP claimed responsibility of every terrorist attack since 2007 and onwards in Pakistan publically and in some cases held press conferences at unknown places to convey their demands and to remain center of attention for the masses (Figure 4). Ironically all the electronic media channels in Pakistan presented every incident of terrorism as breaking news, giving it live coverage with use of extreme sensational words by newscasters.

In Pakistan the TTP had been exploiting media to propagate only their side of agenda, and whenever they felt some journalist or media channel deviated from giving them coverage or file a news against them they either attacked the media channel's office or killed the journalists of the channel. On 18th January 2014 three workers associated with Express News television were killed when unidentified attackers of the TTP ambushed a digital satellite news gathering van in Karachi's Nazimabad area. TTP spokesman Ehsanullah Ehsan in a telephonic interview with Express News channel accepted responsibility of the attack and said it

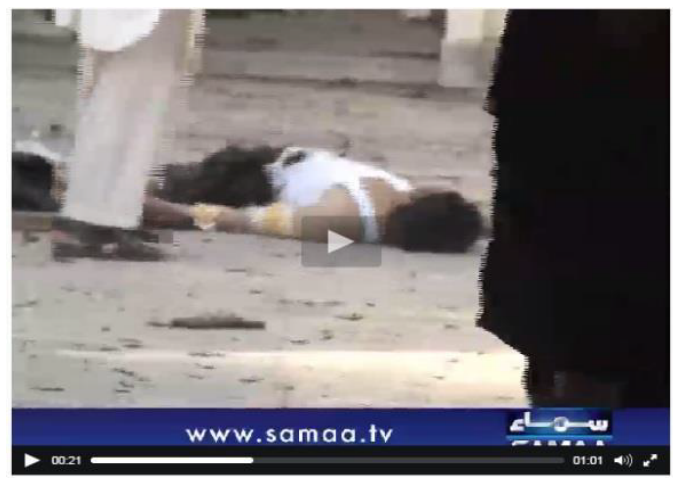

Figure 3: Dead body of suicide bomber of terrorist attack on a mosque in Peshawar on Feb 13, 2014 was being shown by SAMAA TV channel [15]

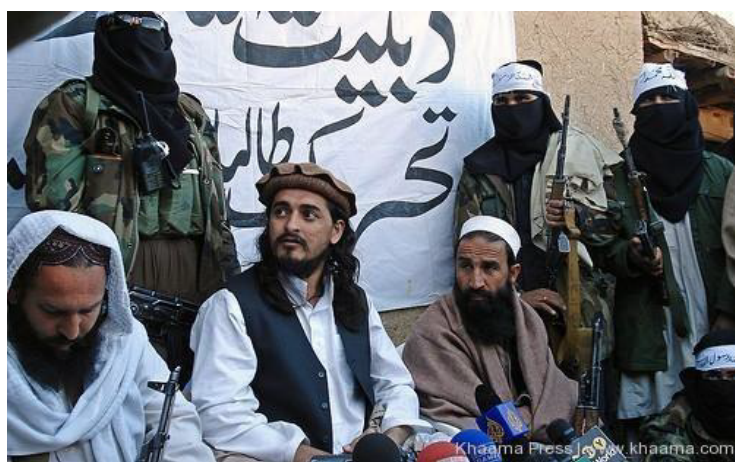

Figure 4: In this picture TTP leader Hakimullah Mahsudis holding a press conference. Microphones of all TV channels including ARY (black), Aj-Jazera TV (Blue), SAMAA (Blue) and Express (Red) are clearly seen in front of him [17]. a reaction for not giving them coverage and broadcasting news against the TTP. "At present, the Pakistani media is playing the role of (enemies and spread) venomous propaganda against the TTP. We warn it again that (they must) side with us in this venomous propaganda. They were killed because they were a part of the propaganda against us." [18]. The TTP spokesman also guaranteed that the group would not harm any staffer of media groups if they would give them proper coverage and refrain from filing propaganda against them. The anchorperson of the program made a deal with the TTP spokesman while compromising on the professionalism and said that the media would give proper coverage to the TTP and in return the media houses or persons should not be attacked [18]. The banned TTP had been killing journalists in FATA, Balochistan and Khyber Pakhtunkhwa (KP) province on publication of news or reports against the TTP. According to a report of "InterMedia. pk" and "Journalistsafety.org" from January 2000 to December 2013 as many as 112 journalists were killed; out of these journalists 18 were killed in KP, 11 in FATA, 20 in Balochistan, 23 in Sindh, 11 in Punjab, three in Islamabad and one in AJK [19]. The purpose of killing staffers of a private TV channel in Karachi, the most populated city of the country, the headquarters of most of the TV channels, and claiming the responsibility was to gain immediate attention of the media groups. The TTP leaders wanted to be treated as accepted and legitimate leaders of the masses. Being the fourth pillar of the society the media outlets are not supposed to treat terrorists or their leaders as legitimate leaders and give them equal coverage as demanded by the TTP spokesman. The problem surfaced when the electronic media channels in a try to surpass each other opted to get interviews of the TTP leaders, broadcasted their statements and press releases as breaking news and showed gruesome aftermaths of terrorist attacks [18]. If it was not media, terrorist outfits comprising of few hundreds to thousand individuals wouldn't stand out in a country of one hundred and eighty million people. It is important to understand that terrorism was empowering and overtaking the minds of people through media's propagandas. The Pakistani people had used to consider the TTP behind every terrorist attack occurred in Pakistan. It was observed that many times multiple disintegrated groups of the TTP with a desire to get cheap publicity accepted the responsibility of a terrorist act in Pakistan. On June $9^{\text {th }} 2014$ terrorists attacked Karachi International Airport and killed as many as 37 people. Soon after the attack the TTP claimed the responsibility and said it was response of killing of former TTP leader Baitullah Mahsud. A day after the TTP statement, the Islamic Movement of Uzbekistan (IMU) released photographs of their fighters to media who they claimed were involved in the assault and were killed in encounter with the Pakistani security forces and said the attack was retaliation of the killing of Uzbeks in Waziristan areas by Pakistani military forces [20]. Similarly, on November $2^{\text {nd }} 2014$ a suicide explosion took place near Wagha border in Pakistan killing 60 people. Three different groups of the TTP including the TTP, Jundallah group and Jamaat-ul-Ahrar claimed the responsibility of the terrorist attack [6]. Terrorists and militant groups were never as strong as they are considered now days. History reveal sterrorist groups like Tamil Tiger, Irish separatists emerged fought with the states and no matter how much stronger and organized they were but ultimately got eliminated. The Liberation Tigers of Tamil Eelam (LTTE) who were also known as Tamil Tigers started insurgency in Sri Lanka on 23 July 1983 for an independent Tamil state. After a 26-year military campaign, the Sri Lankan military defeated the Tamil Tigers in May 2009 and brought the civil war to an end [21]. One of the main strategies adopted by Sri Lankan military was to restrict the media from being given the news, statements the LTTE or the details of military operation and ultimately got the country liberated from terror [22]. The UK government also imposed restrictions on media including $\mathrm{BBC}$ 
during Irish Separatists movement BBC [23-24].

\section{The TTP and terrorism in Pakistan}

Many not all Deobandi Madrassas and mosques provided a pool of recruits for the TTP in Pakistan and played a vital role in emergence of Tehrik-e-Taliban [16] and the TTP. The "Jihadis" (militants) who fought in Afghanistan at the time of Soviet invasion back in 1980s with the indirect support of US Central Intelligence Agency and direct support of Pakistani Inter-Services Intelligence directorate (ISI) were later turned to Taliban [25-27]. After the post-cold war era, the TTP re-emerged as a group in Pakistan especially after December 2007 in the wake of a military operation against a Deobandi Madrassa of radical clerics Maulana Aziz and his brother Maulana Rasheed of Lal Mosque in federal capital of Pakistan [28]. The two hardcore clerics, who idealized Al-Qaeda leader Osama bin Laden and the Taliban leader Mullah Omar, wanted to vehemently impose "Sharia" (Extreme Islamic interpretation) in Pakistan [29]. They took support of the strong Pakistani media. On their directives the male and female students of the seminary got involved in certain illegal activities while the clerics were found rationalizing those acts on media in the name of religion. Sensational media coverage of the two clerics and illegal acts of the seminary students including assault on police officials (Figure 5), kidnapping of foreigners, setting up of Sharia Court, burning of CDs' after snatching from shops (Figure 6), occupation of a children library in Islamabad the capital of Pakistan made it a hot topic of discussion for general public and the whole nation was shocked at the happening in capital city.

The role of media was largely criticized before and after the military operation on Lal Mosque and the seminary. Sensational media coverage of the issue and interviews of the clerics by even foreign channels made the normal life paralyzed in federal capital and gave much popularity to them in no time. The two clerics who were otherwise not even known at their native town became very popular in the country and emerged as religious heroes. The statement of Maulana Abdul Aziz that "Madrassa students would even sacrifice their lives in case of any operation by the government" was twisted by electronic media and gave an impression that Maulana was warning presence of suicidal bombers inside the mosque. Grand Mufti of Pakistan "Mufti Rafi Uthmani" who was involved in talks with Ghazi brothers on behalf of the government also blamed media of distorting the facts [32]. The government did not allow Police to conduct operation against the hardcore clerics and students of Lal Mosque rather Special Service Group (SSG) of Pakistan Army conducted the operation due to media reports about presence of suicide bombers inside the mosque. The killing of 91 seminary students, most of them from FATA areas created resentment in tribal people against Pakistan Army and the TTP who was monitoring the whole episode through the media, exploited the sentiments of FATA people and started terrorist activities against security forces in the name of revenge [33]. The other reason that led to the TTP hostility against Pakistan was its support to US war on terrorism in Afghanistan because the TTP suffered huge in US drone strikes inside FATA areas including killing of the TTP leaders Nek Muhammad, Baitullah, Hakimullah and other [34]. The TTP claimed its aggression as a struggle for imposition of "Islamic Sharia" in Pakistan and assaulted religious plurality of the country by attacking mosques, funeral prayers, and Sufi Shrines of other Islamic sects in addition to targeting the worship places of minorities, lives of civilians and innocent students. After the death of TTP leader Baitullah Mahsud in a US drone attack in 2009, Hakimullah Mahsud managed to show his military strength when he took some 250 Pakistani soldiers hostage for more than two months in South Waziristan. Exploiting

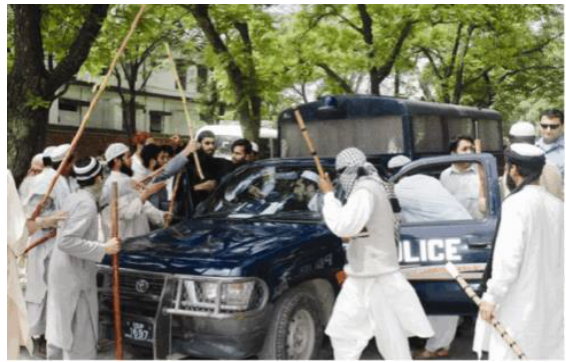

Figure 5: Assault by seminary students of Lal Mosque on police mobile [30].

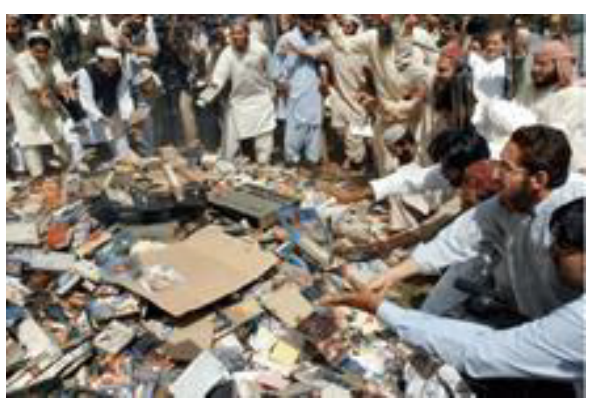

Figure 6: Students of Lal Mosque burning CDs after forcefully snatching from a CD shop [31]

the media he succeeded to become leader of TTP after Baitullah [35]. Although Hakimullah Mahsud succeeded Baitullah as TTP leader, but rift among different TTP groups created so many TTP fictions and every group chose its own leader. These Taliban groups got engaged in terrorist activities throughout Pakistan and even in Afghanistan. Due to the critical role of the media and the exploitation by the TTP in the wake of a tragic incident of terrorist attack on Army Public School in Peshawar in which more than 130 innocent students were ruthlessly killed, the government of Pakistan in consultation with the parliament passed a bill and restricted the media from giving coverage to the TTP leaders or their activities or terrorist attacks.

\section{Discussion}

What Pakistan is facing in the form of enhanced wave of terrorism has the major share of media sensationalism. Unfortunately, at times it appears that, freedom of media in Pakistan is mostly misused. We have argued through critical analysis of terrorism reporting that use sensational language is a common practice in reporting in electronic media not only in developing countries like Pakistan where challenges are diverse but also across the world for political and financial manipulation and gains. A few checks on the media relating to the coverage of terrorist incidents are imperative and the media should have to accept those checks and does not insist on unbridled freedom of expression as it can play havoc with consumers. The unhealthy psychological effects of sensational media reports on human lives cannot be overlooked.

\section{Conclusion}

Media channels should have to use simple language in news and reporters must be asked not to use sensational words especially when giving live coverage of any sensitive issue because sensational language leaves unhealthy psychological effects. The competition of breaking a piece of news has been most treacherous for the people 
Citation: Haider SA (2016) A Critical Study of how the Taliban Capitalize on Electronic Media Sensationalism in Pakistan. J Mass Communicat Journalism 6: 292. doi:10.4172/2165-7912.1000292

Page 5 of 5

and embarrassing for the state as well. Presenting comments of leaders of terrorists' bodies by private as well as state owned media houses across the world and even showing their press releases gives an encouragement to terrorists' entities to expand their influence among masses. Investigative reporting or probe is a serious business and if media groups and journalists start relying on terrorists' incidents, press releases, interviews to give breaking news then of course it could land them into trouble and terrorists would expect more from them.

\section{References}

1. Davey GCL (2012) The Psychological Effects of TV News.

2. Extra Sensationalism (2013) Extra Extra! Sensationalism in Journalism.

3. http://dunyanews.tv/index.php/en/Pakistan/225074-Uzbek-terrorists-claimresponsibility-of-Karachi-A

4. Rogers T (n.d.) Is Sensationalism in the News Media a Bad Thing? About news, Accessed on: 25 November 2014

5. https://en.wikipedia.org/wiki/Sensationalism\#cite_note-fair-1

6. https://en.wikipedia.org/wiki/2014_Wagah_border_suicide_attack

7. Daly J (2014) Media Sensationalism is Damaging Still Better than Bias.

8. Rind A (2010) Is Pakistani Media Glorifying Terrorism? LUBP, Accessed on: 10 October 2010.

9. Stanley P (2012) Americans Depend on TV, Online Media for Political News; Print Media Sees Steep Decline, The Christian Post. CP Politics Accessed on: 3 October 2012.

10. https://en.wikipedia.org/wiki/Media_of_Pakistan

11. Indian Media (n.d.) Indian Media Against Pakistan Compilation Collection of Indian Media Talking Against Pakistan.

12. Pakistan Media (2013) Pakistan Media Commission Review.

13. HassanR (2010) Media Boom: 90 Channels, 106 FM stations in 10 years. View point, Accessed on: 23 September 2010.

14. APP, (n.d.) (2009) PEMRA issued 71 licenses for establishment of private TV channels, NA told, Asia, Report. Pakistan: The militant jihadi challenge.

\section{5. http://urdu.samaa.tv/pakistan/13-Feb-2015/26986}

16. Mir H (2013) Maulana Fazlullah in the eyes of Malala. Pakistan Gender News Accessed on: 9 november November 2013.

17. http://www.khaama.com/dangerous-disarray-reported-among-pakistanitaliban-leaders-2544

18. Journalists (2014) How a triple murder in Karachi left the Taliban not just making headlines, but writing them, too.

19. Journalists killed (2013). Journalists Killed in Pakistan.

20. Video (2015) Picture of Suicidal mission broadcasted by media.

21. Dunya News (2014) Uzbek terrorists claim responsibility of Karachi Airport siege.

22. McRaith C (2012) Arbitrary detention in post-conflict Sri Lanka.

23. NA Smith (2010) Understanding Sri Lanka's Defeat of the Tamil Tigers.

24. BBC Urdu (2014) Media should care while giving news of terrorism.

25. Bajoria J, Zachary L (2013) Pakistan's New Generation of Terrorists. CFR 55 10-11.

26. Hanni A, HegiL (2013) The Pakistani Godfather: The Inter-Services Intelligence and the Afghan Taliban 1994-2010. Small Wars Journal 9: 4-6.

27. Iftikhar A K (2014) Lal Masjid Operation led to Creation of TTP.

28. Khaled A (2012) Lal Masjid Facts Won't Go Away. The Express Tribune, Accessed on: 16 December 2012

29. Rageh O (2007) Witness Special - Inside the Lal Masjid (Red Mosque).

30. https://presidentmusharraf.wordpress.com/2008/08/21/musharraf-lal-masjid

31. https://presidentmusharraf.wordpress.com/2008/08/21/musharraf-lal-masjid

32. Lal Masjid (2012) Lal Masjid Operation: A factual Analysis of its Background The Operation Itself and the Aftermath.

33. Hussain AH (2014) Pakistani Taliban Tactics Spread Silent Fear. Asia Times, Accessed on: 26 march 2014.

34. Brumfield B (2012) Who are the Pakistani Taliban? CNN.

35. http://www.jamestown.org/single/?tx_ttnews $\% 5 B t t \_n e w s \% 5 D=37628 \#$ VvOHyeJ97Z4 